\title{
Intermetallic Reactions in Reflowed and Aged Sn-9Zn Solder Ball Grid Array Packages with Au/Ni/Cu and Ag/Cu Pads
}

\author{
HSIU-JEN LIN ${ }^{1}$ and TUNG-HAN CHUANG ${ }^{1,2}$ \\ 1.-Institute of Materials Science and Engineering, National Taiwan University, Taipei 106, Tai-
} wan. 2.—E-mail: tunghan@ccms.ntu.edu.tw

During the reflowing of Sn-9Zn solder ball grid array (BGA) packages with $\mathrm{Au} / \mathrm{Ni} / \mathrm{Cu}$ and $\mathrm{Ag} / \mathrm{Cu}$ pads, the surface-finished $\mathrm{Au}$ and $\mathrm{Ag}$ film dissolved rapidly and reacted with the $\mathrm{Sn}-9 \mathrm{Zn}$ solder to form a $\gamma_{3}-\mathrm{AuZn}_{4} / \gamma-\mathrm{Au}_{7} \mathrm{Zn}_{18}$ intermetallic double layer and $\varepsilon-\mathrm{AgZn}_{6}$ intermetallic scallops, respectively. The growth of $\gamma_{3}-\mathrm{AuZn}_{4}$ is prompted by further aging at $100^{\circ} \mathrm{C}$ through the reaction of $\gamma-\mathrm{Au}_{7} \mathrm{Zn}_{18}$ with the $\mathrm{Zn}$ atoms dissolved from the $\mathrm{Zn}$-rich precipitates embedded in the $\beta$-Sn matrix of $\mathrm{Sn}-9 \mathrm{Zn}$ solder BGA with $\mathrm{Au} / \mathrm{Ni} / \mathrm{Cu}$ pads. No intermetallic compounds can be observed at the solder/pad interface of the Sn-9Zn BGA specimens aged at $100^{\circ} \mathrm{C}$. However, after aging at $150^{\circ} \mathrm{C}$, a $\mathrm{Ni}_{4} \mathrm{Zn}_{21}$ intermetallic layer is formed at the interface between $\mathrm{Sn}-9 \mathrm{Zn}$ solder and $\mathrm{Ni} / \mathrm{Cu}$ pads. Aging the immersion $\mathrm{Ag}$ packages at $100^{\circ} \mathrm{C}$ and $150^{\circ} \mathrm{C}$ caused a $\gamma-\mathrm{Cu}_{5} \mathrm{Zn}_{8}$ intermetallic layer to appear between $\varepsilon-\mathrm{AgZn}_{6}$ intermetallics and the $\mathrm{Cu}$ pad. The scallop-shaped $\varepsilon-\mathrm{AgZn}_{6}$ intermetallics were found to detach from the $\gamma-\mathrm{Cu}_{5} \mathrm{Zn}_{8}$ layer and float into the solder ball. Accompanied with the intermetallic reactions during the aging process of reflowed Sn-9Zn solder BGA packages with $\mathrm{Au} / \mathrm{Ni} / \mathrm{Cu}$ and $\mathrm{Ag} / \mathrm{Cu}$ pads, their ball shear strengths degrade from $8.6 \mathrm{~N}$ and $4.8 \mathrm{~N}$ to about $7.2 \mathrm{~N}$ and $2.9 \mathrm{~N}$, respectively.

Key words: Intermetallic compounds, $\mathrm{Sn}-9 \mathrm{Zn}, \mathrm{Au} / \mathrm{Ni} / \mathrm{Cu}$ pads, $\mathrm{Ag} / \mathrm{Cu}$ pads, ball shear strength

\section{INTRODUCTION}

Out of environmental concerns, the development of $\mathrm{Pb}$-free solders has become a key issue for the electronics industry. Compared to many other promising $\mathrm{Pb}$-free solders, such as $\mathrm{Sn} 3.5 \mathrm{Ag}, \mathrm{Sn} 0.7 \mathrm{Cu}$, and $\mathrm{Sn}-\mathrm{Ag}-\mathrm{Cu}$, eutectic $\mathrm{Sn}-9 \mathrm{Zn}$ has the merits of a lower melting point $\left(199^{\circ} \mathrm{C}\right)$ and better cost performance. ${ }^{1}$ However, further research efforts are required to address its disadvantages, such as poor wettability and oxidation resistance, so that the improvements made on eutectic Sn-9Zn can facilitate the development of an actual replacement for $\mathrm{Sn}-\mathrm{Pb}$ solders. In addition, the reliability of $\mathrm{Sn}-9 \mathrm{Zn}$ solder joints on various surface-finished pads for electronic packaging should also be evaluated.

The Au/Ni surface finish has been widely used for printed circuit boards to protect $\mathrm{Cu}$ pads from oxidation and promote the wettability of liquid solder. ${ }^{2}$ During the reflow process, the Au thin film dissolves

(Received May 2, 2005; accepted August 30, 2005) rapidly into the solder matrix, triggering the occurrence of further interfacial reaction between the solder and the Ni substrate. In the cases of traditional $\mathrm{Sn}-\mathrm{Pb}$ solders and most $\mathrm{Pb}$-free solders (such as $\mathrm{Sn}$ $\mathrm{Ag}, \mathrm{Sn}-\mathrm{Cu}$, and $\mathrm{Sn}-\mathrm{Bi}$ ), their reactions with $\mathrm{Ni}$ substrates lead to the formation of $\mathrm{Ni}_{3} \mathrm{Sn}_{4}$ intermetallic compounds. $^{3-5}$ However, a liquid Sn-Zn solder alloy reacts with $\mathrm{Ni}$ to form $\mathrm{Ni}_{19.0} \mathrm{Zn}_{80.0} \mathrm{Sn}_{1.0}$ intermetallics due to the high activity of the element $\mathrm{Zn} .{ }^{6} \mathrm{~A}$ soldering reaction between liquid $\mathrm{Sn}-8 \mathrm{Zn}-3 \mathrm{Bi}$ and $\mathrm{Ni}$ substrate was reported to result in a continuous intermetallic layer of $\mathrm{Ni}_{5} \mathrm{Zn}_{21}$ at temperatures below $325^{\circ} \mathrm{C}$ and a double layer of $\mathrm{Ni}_{5} \mathrm{Zn}_{21} / \mathrm{Ni}_{35} \mathrm{Zn}_{22} \mathrm{Sn}_{43}$ at above $325^{\circ} \mathrm{C}{ }^{7}$ Harris also showed that a solid/solid interfacial reaction between $\mathrm{Sn}-\mathrm{Zn}-\mathrm{Bi}$ solder and $\mathrm{Ni}$ substrate at $125^{\circ} \mathrm{C}$ for 100 days caused the formation of a Ni-85.9wt.\%Zn intermetallic compound. ${ }^{8}$ In addition, Shiue et al. aged a series of Sn-Zn based solders joined with $\mathrm{Au} / \mathrm{Ni}-\mathrm{P} / \mathrm{Cu}$ substrates and reported an intermetallic compound of $\mathrm{Zn}$-rich $\gamma$ phase $\left(\mathrm{NiZn}_{3}\right)$ at the interface. ${ }^{9}$

For the $\mathrm{Pb}$-free BGA packages with $\mathrm{Au} / \mathrm{Ni} / \mathrm{Cu}$ 
pads, various failures such as Au embrittlement and black pads have been reported..$^{2}$ In addition, the $\mathrm{Au} /$ $\mathrm{Ni}$ electro- or electroless-plating process is quite costly and complex. Immersion silver is an effective alternative method for the surface finishing of $\mathrm{Cu}$ pads. The process involving immersion Ag takes about $7 \mathrm{~min}$, and the cost is close to that of processes involving traditional $\mathrm{Sn} .{ }^{3}$ Immersion Ag can provide smooth surfaces and good wettability for liquid solders on $\mathrm{Cu}$ pads. During reflow, the Ag metallization (about $0.2 \mu \mathrm{m}$ in thickness) also dissolves rapidly into the solder matrix, causing the intermetallic reactions at the interfaces between the solder alloy and the $\mathrm{Cu}$ pads.

For the interfacial reactions of $\mathrm{Sn}-\mathrm{Pb}$ solders and most $\mathrm{Pb}$-free solders with $\mathrm{Cu}$ pads, $\mathrm{Cu}_{6} \mathrm{Sn}_{5}$ and $\mathrm{Cu}_{3} \mathrm{Sn}$ intermetallic compounds have also been reported. ${ }^{10}$ However, a $\mathrm{Sn}-\mathrm{Zn} / \mathrm{Cu}$ interfacial reaction was reported to generate $\mathrm{Cu}-\mathrm{Zn}$ intermetallics on account of the high activity of the element $\mathrm{Zn}$. Chan et al. studied the soldering reactions between liquid Sn-9Zn and $\mathrm{Cu}$ substrates and found $\mathrm{Cu}_{33.4} \mathrm{Zn}_{66.5} \mathrm{Sn}_{0.1}$ at the interfaces. ${ }^{11}$ Suganuma et al. also investigated the soldering reactions between liquid $\mathrm{Sn}-\mathrm{Zn}$ and $\mathrm{Cu}$ substrates at temperatures ranging from $230^{\circ} \mathrm{C}$ to $280^{\circ} \mathrm{C}$ for $5-35 \mathrm{~min} .^{12}$ Three layers of interfacial intermetallic compounds $\left(\gamma-\mathrm{Cu}_{5} \mathrm{Zn}_{8}, \beta^{\prime}-\right.$ $\mathrm{CuZn}$, and an unknown thin-layer phase) were found. The total thickness of these intermetallics increased with the increasing $\mathrm{Zn}$ content in the $\mathrm{Sn}-\mathrm{Zn}$ solders. Lin and Chuang further analyzed the intermetallic reactions between liquid Sn-8Zn-3Bi solder and $\mathrm{Cu}$ substrates in a wide temperature range of $225-350^{\circ} \mathrm{C}$ for $30-90$ min. ${ }^{13}$ The results indicated that a planar layer of $\mathrm{Cu}_{32.1} \mathrm{Zn}_{66.7} \mathrm{Sn}_{0.7} \mathrm{Bi}_{0.5}$ ( $\gamma$ phase) along with a great number of scallop-shaped intermetallic compounds of $\mathrm{Cu}_{19.3} \mathrm{Zn}_{77.8} \mathrm{Sn}_{2.9}$ ( $\varepsilon$ phase) appeared at the interfaces at temperatures below $325^{\circ} \mathrm{C}$. At temperatures higher than $325^{\circ} \mathrm{C}$, the $\varepsilon$-intermetallic scallops disappeared, and the planar $\gamma$-intermetallics became cluster shaped. For

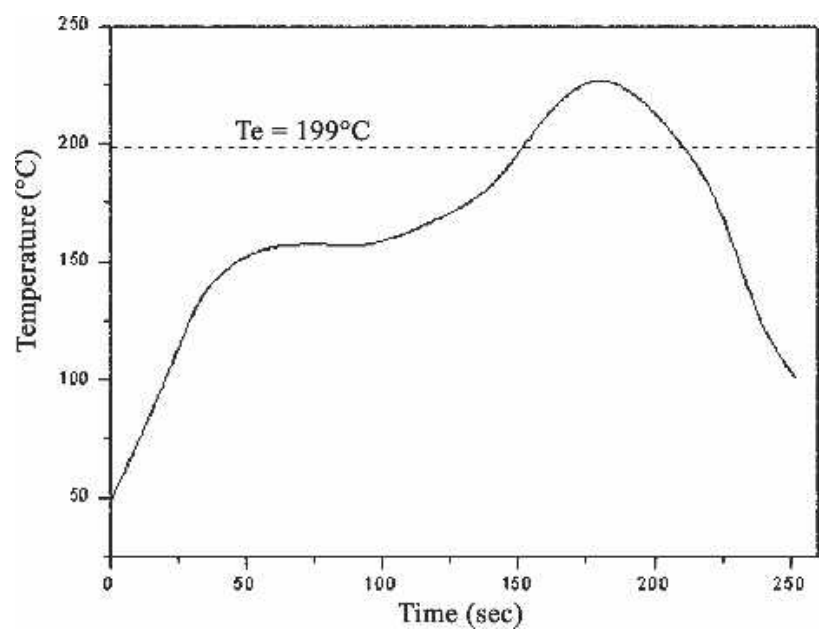

Fig. 1. Temperature profile of the reflow process for $\mathrm{Sn}-9 \mathrm{Zn}$ solder $\mathrm{BGA}$ packages in this study with $\mathrm{Au} / \mathrm{Ni} / \mathrm{Cu}$ and $\mathrm{Ag} / \mathrm{Cu}$ pads. the solid/solid interfacial reactions between various $\mathrm{Sn}-\mathrm{Zn}$ solders and $\mathrm{Cu}$ substrates, Lee et al. ${ }^{14}$ and Yoon et al. ${ }^{15,16}$ reported a $\gamma-\mathrm{Cu}_{5} \mathrm{Zn}_{8}$ intermetallic compound after aging at $100^{\circ} \mathrm{C}, 130^{\circ} \mathrm{C}$, and $160^{\circ} \mathrm{C}$. In addition, Harris showed that $13-\mu \mathrm{m}$-thick $\gamma-\mathrm{Cu}_{5} \mathrm{Zn}_{8}$ intermetallics appeared at the $\mathrm{Sn}-\mathrm{Zn}-\mathrm{Bi} /$ $\mathrm{Cu}$ interface after aging at $125^{\circ} \mathrm{C}$ for 100 days. ${ }^{8}$ This study focused on the intermetallic reactions and related bonding strengths of the eutectic Sn-9Zn solder joints in a ball grid array (BGA) package with $\mathrm{Au} / \mathrm{Ni} / \mathrm{Cu}$ and $\mathrm{Ag} / \mathrm{Cu}$ pads after the reflow and aging processes.
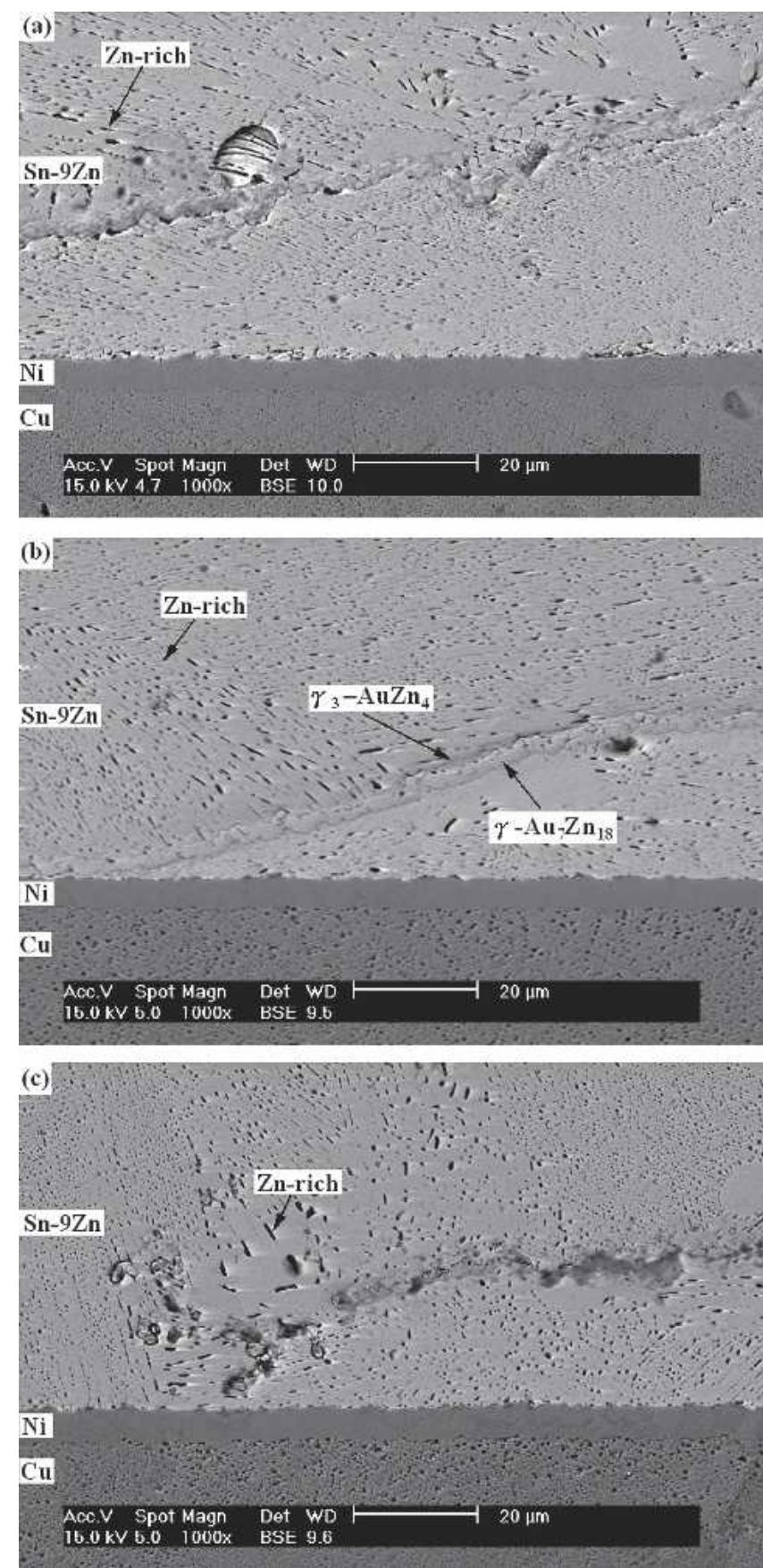

Fig. 2. Morphology of the floating intermetallic layers in Sn-9Zn solder BGA packages with $\mathrm{Au} / \mathrm{Ni} / \mathrm{Cu}$ pads after multiple reflows: (a) one time, (b) two times, and (c) three times. 


\section{EXPERIMENTAL PROCEDURE}

Ball grid array packages with $\mathrm{Au} / \mathrm{Ni} / \mathrm{Cu}$ pads were electroplated with a 5- $\mu \mathrm{m}$-thick layer of $\mathrm{Ni}$ and immersion plated with a $0.5-\mu \mathrm{m}$-thick layer of $\mathrm{Au}$, while those with $\mathrm{Ag} / \mathrm{Cu}$ pads were immersion deposited with a $0.2-\mu \mathrm{m}$-thick layer of Ag. Sn-9Zn (wt.\%) solder balls of $0.4 \mathrm{~mm}$ in diameter were dipped in rosin mildly activated (RMA) flux, placed on the Au/ $\mathrm{Ni}$ and $\mathrm{Ag}$ surface finished $\mathrm{Cu}$ pads, and then reflowed in a hot air furnace equipped with five heating zones. Figure 1 shows the temperature profile adopted for the reflow process. During reflow, liquid $\mathrm{Sn}-9 \mathrm{Zn}$ solder reacted with $\mathrm{Au} / \mathrm{Ni} / \mathrm{Cu}$ and $\mathrm{Ag} / \mathrm{Cu}$ pads to form intermetallic compounds at the interfaces.

For further evaluation of the intermetallic reactions in Sn-9Zn BGA packages as electronic devices were in operation and the solder joints were being heated, certain reflowed specimens were aged at $100^{\circ} \mathrm{C}$ and $150^{\circ} \mathrm{C}$ for various time periods, and a solid/solid reaction was observed to occur at the solder/pad interface under this condition.

The BGA packages, after reflow and aging, were cross-sectioned through a row of Sn-9Zn solder balls. They were then cold-mounted, ground with 1500 grit $\mathrm{SiC}$ paper, and polished with $0.3-\mu \mathrm{m}$ alumina powder. The morphology and chemical composition of intermetallic compounds were analyzed using a
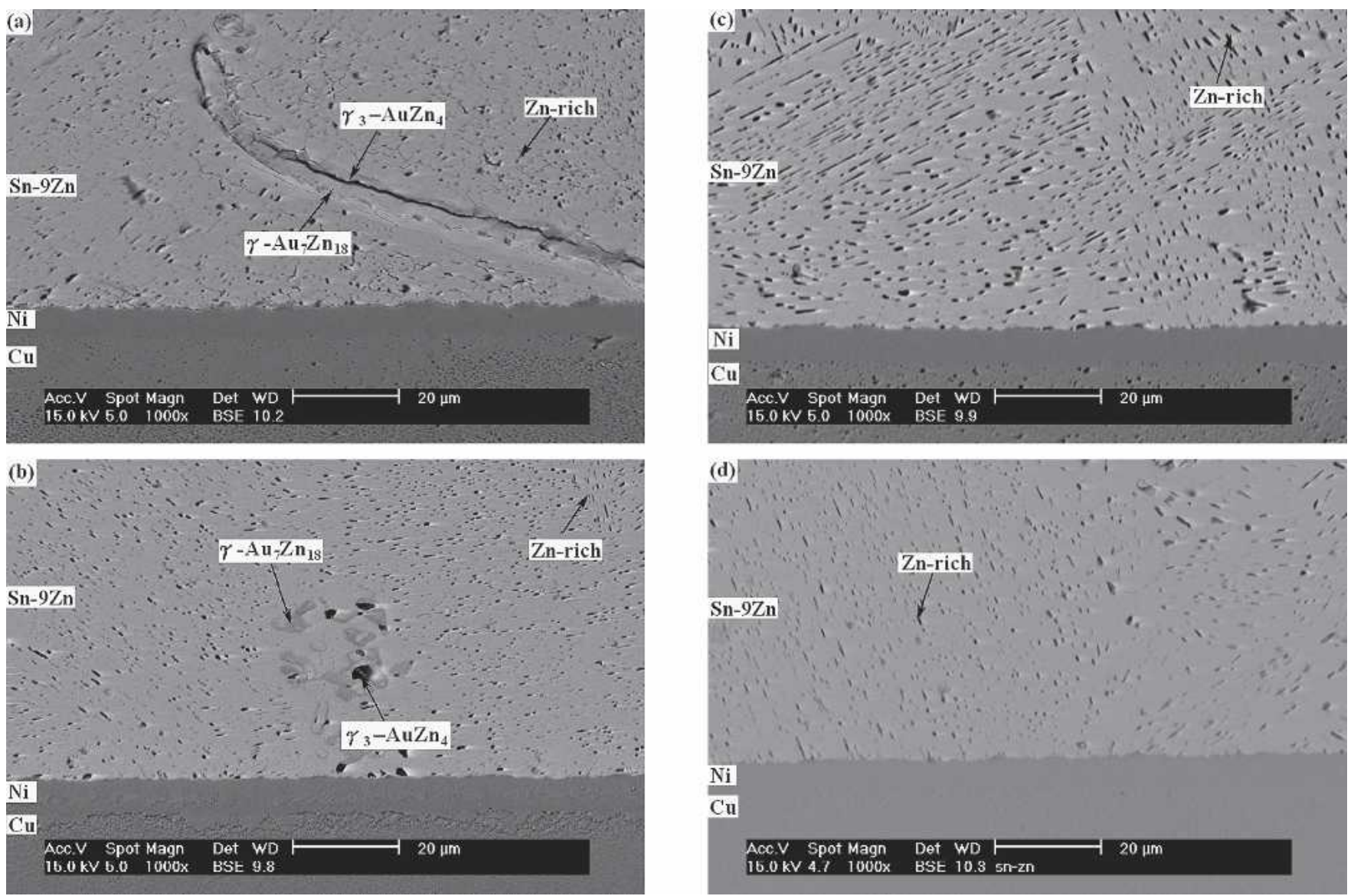

Fig. 3. Microstructure of the Sn-9Zn solder joints in BGA packages with $\mathrm{Au} / \mathrm{Ni} / \mathrm{Cu}$ pads after aging at $100^{\circ} \mathrm{C}$ for various times: (a) $100 \mathrm{~h}$, (b) 500 $\mathrm{h},(\mathrm{c}) 700 \mathrm{~h}$, and (d) $1000 \mathrm{~h}$.

scanning electron microscope equipped with energydispersive x-ray spectrometry (EDX). Finally, ball shear tests were conducted to measure the bonding strengths of the solder joints. For this purpose, a shear rate of $0.1 \mathrm{~mm} / \mathrm{s}$ and a shear height of $80 \mu \mathrm{m}$ (about 1/4 the reflowed ball height) were employed.

\section{RESULTS AND DISCUSSION}

The microstructure of the Sn9Zn solder BGA packages with $\mathrm{Au} / \mathrm{Ni} / \mathrm{Cu}$ pads after multiple reflows is shown in Fig. 2. The solder matrix contains many needle-shape Zn-rich precipitates embedded in the $\beta$-Sn matrix. The $\mathrm{Zn}$ content in the $\beta$-Sn matrix, as analyzed by EDX, is 2.2 wt.\% (4 at.\%). During the reflow process, the $\mathrm{Au}$ thin film on $\mathrm{Au} / \mathrm{Ni} / \mathrm{Cu}$ pads dissolves rapidly, and the resultant intermetallic compounds that are formed at the solder/pad interfaces take the appearance of a planar double layer. The intermetallic layer tends to float away from the interfaces even after the first reflow (Fig. 2). Increasing the reflow cycles causes the intermetallic compounds to float farther away. The composition (at.\%) of the inner layer of the intermetallics, as analyzed by EDX, is Au:Zn = 28.9:71.1, which corresponds to the $\gamma$ phase $\left(\mathrm{Au}_{7} \mathrm{Zn}_{18}\right)$ in the $\mathrm{Au}-\mathrm{Zn}$ equilibrium diagram. The outer intermetallic layer has a higher $\mathrm{Zn}$ content (Au:Zn = 18.7:81.3), which corresponds to the $\gamma_{3}$ phase $\left(\mathrm{AuZn}_{4}\right)$ in the $\mathrm{Au}-\mathrm{Zn}$ equilibrium diagram. The microstructure of the $\mathrm{Sn}-9 \mathrm{Zn}$

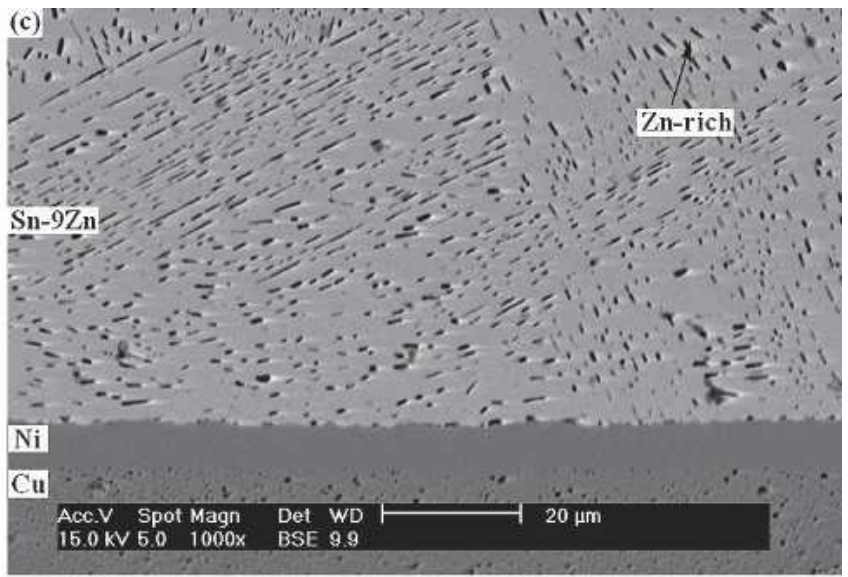



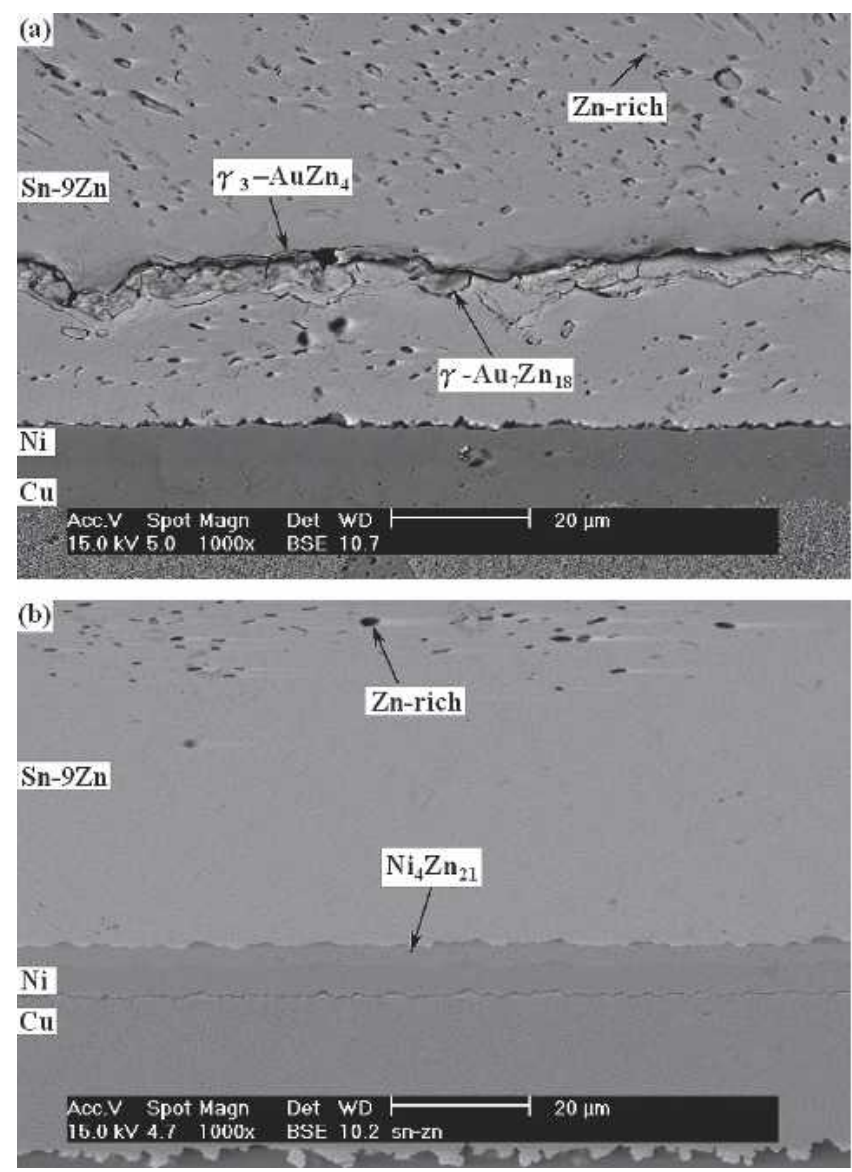

Fig. 4. Microstructure of the Sn-9Zn solder joints in BGA packages with Au/Ni/Cu pads after aging at $150^{\circ} \mathrm{C}$ for various times: (a) $100 \mathrm{~h}$, (b) 500 h, (c) $700 \mathrm{~h}$, and (d) $1000 \mathrm{~h}$.
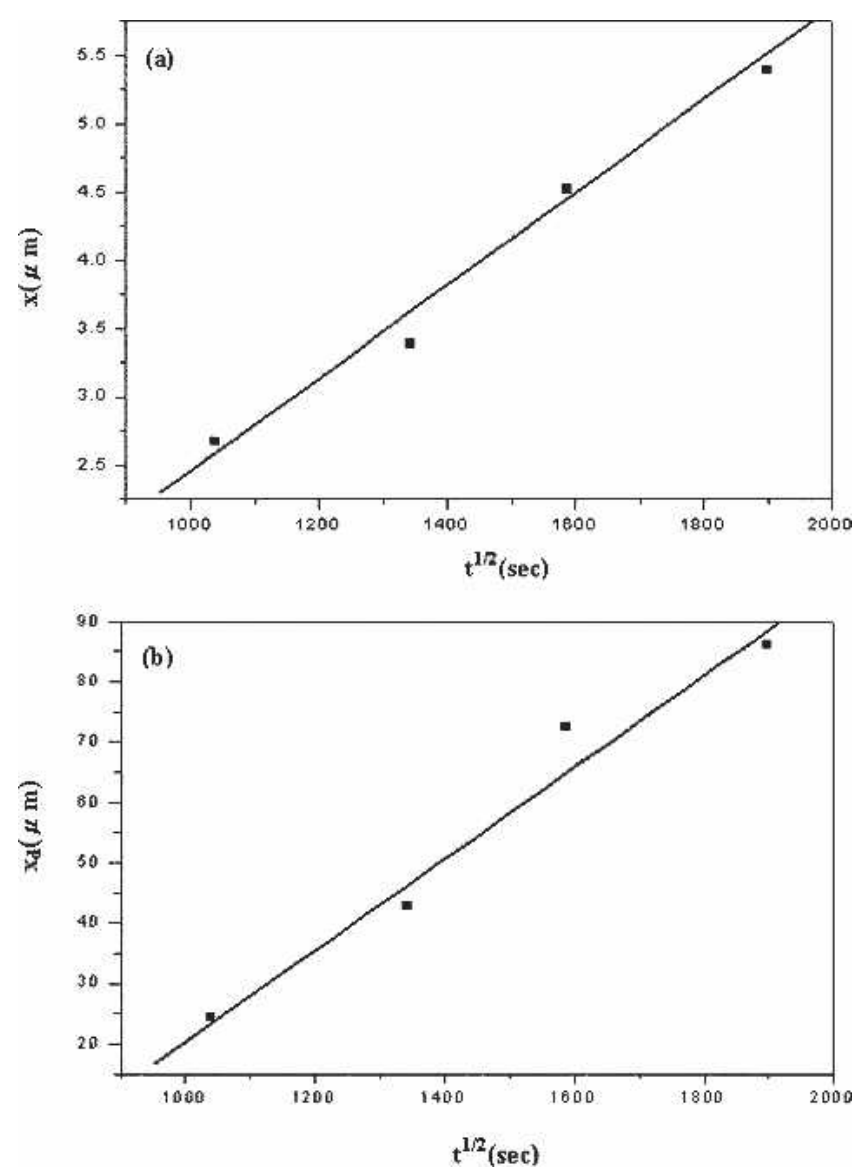

Fig. 5. Thickness $(x)$ of the $\mathrm{Ni}_{4} \mathrm{Zn}_{21}$ interfacial intermetallic layer and precipitate-free zone $\left(x_{d}\right)$ in the solder matrix of $\mathrm{Au} / \mathrm{Ni}$ surface finished $\mathrm{Sn}-9 \mathrm{Zn} \mathrm{BGA}$ packages after aging at $150^{\circ} \mathrm{C}$ relative to the square root of time $\left(\mathrm{t}^{1 / 2}\right)$.
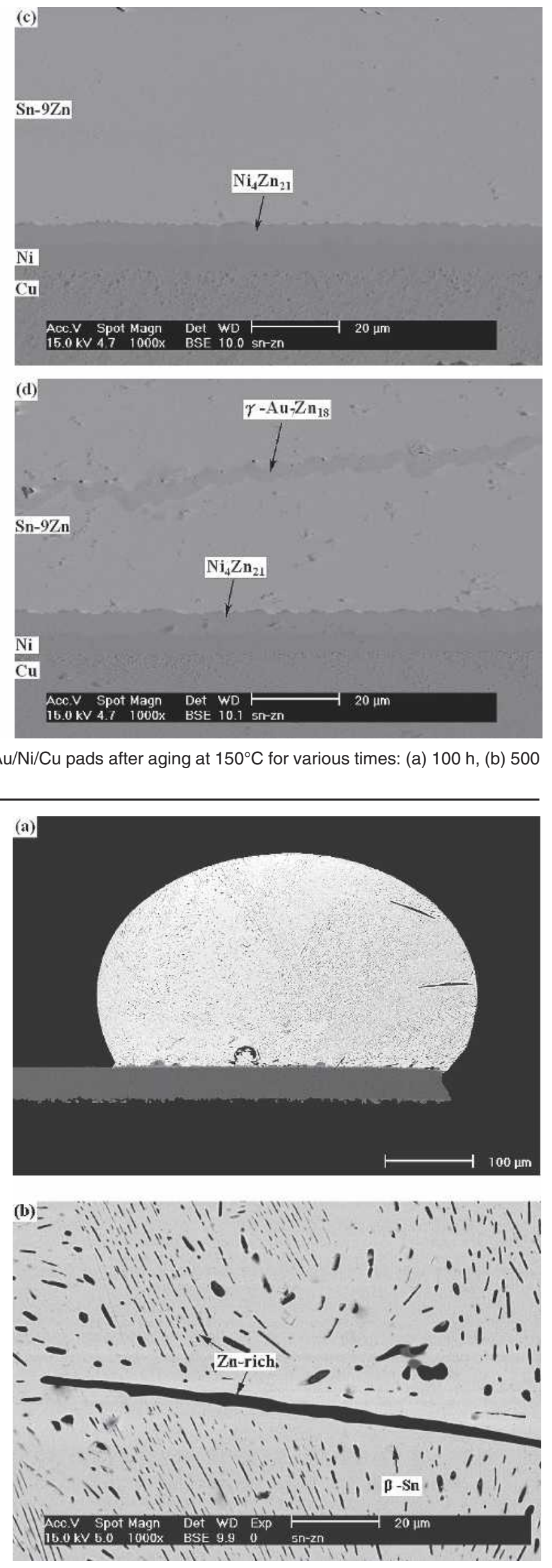

Fig. 6. Morphology of (a) the as-reflowed Sn-9Zn solder ball with $\mathrm{Ag} / \mathrm{Cu}$ and (b) the microstructure of the as-reflowed $\mathrm{Sn}-9 \mathrm{Zn}$ matrix. 
solder joints remains unchanged after aging at $100^{\circ} \mathrm{C}$, as evidenced by Fig. 3. However, the $\gamma_{3^{-}}$ $\mathrm{AuZn}_{4}$ intermetallic layer grows with the diminishing of $\gamma-\mathrm{Au}_{7} \mathrm{Zn}_{18}$ as the aging time increases, and the $\mathrm{Zn}$ content in the $\beta$-Sn matrix increases slightly to 2.3 wt.\% (4.2 at.\%). Following the floating away of the $\gamma_{3} / \gamma$ intermetallic layer, no further intermetallic reaction can be observed at the interface between the $\mathrm{Sn}-9 \mathrm{Zn}$ solder and the $\mathrm{Ni} / \mathrm{Cu}$ pad even after a prolonged aging time of $1000 \mathrm{~h}$.

However, aging at $150^{\circ} \mathrm{C}$ causes a planar intermetallic phase to form at the solder/pad interface of $\mathrm{Au} / \mathrm{Ni}$ surface finished $\mathrm{Sn}-9 \mathrm{Zn}$ BGA packages, as shown in Fig. 4. The EDX analysis indicates that the composition (at.\%) of these interfacial intermetallics is $\mathrm{Ni}: \mathrm{Zn}=16.1: 83.9$, which corresponds to the $\mathrm{Ni}_{4} \mathrm{Zn}_{21}$ phase; also, the $\mathrm{Zn}$ content in the $\beta$-Sn matrix is increased slightly further to 2.4 wt.\% (4.3 at.\%). Figure 4 reveals that the $\mathrm{Ni}_{4} \mathrm{Zn}_{21}$ intermetallic layer grows with the increase in aging time at $150^{\circ} \mathrm{C}$. The thickness of the $\mathrm{Ni}_{4} \mathrm{Zn}_{21}$ intermetallic layer is measured and plotted against the square root of aging time $\left(\mathrm{t}^{1 / 2}\right)$, as shown by Fig. 5a, where the linear relation of the curve indicates that the intermetallic growth is diffusion controlled. Figure 4 also indicates that the growth of $\mathrm{Ni}_{4} \mathrm{Zn}_{21}$ intermetallic compounds causes the depletion of Zn-rich precipitates in the solder balls near the $\mathrm{Ni} / \mathrm{Cu}$ pads. The result indicates that the $\mathrm{Ni}_{4} \mathrm{Zn}_{21}$ intermetallics are formed through the interfacial reaction of the $\mathrm{Ni}$ layer with the $\mathrm{Zn}$ atoms from the solder matrix. The consumption of $\mathrm{Zn}$ content in the $\mathrm{Sn}-9 \mathrm{Zn}$ solder caused the dissolution of Zn-rich precipitates near the solder/pad interfaces. Figure 5b shows that the thickness of precipitation-free zones increases parabolically with the aging time, giving the implication that the reaction is diffusion controlled. The lattice diffusivity of $\mathrm{Zn}$ in the $\mathrm{Sn}$ matrix at $150^{\circ} \mathrm{C}$, as calculated from the equation of Huang and Huntington, ${ }^{17}$

$$
\mathrm{D}\left(\mathrm{m}^{2} / \mathrm{s}\right)=1.1 \times 10^{-6} \exp \left(-\frac{50.2 \mathrm{~kJ} / \mathrm{mol}}{\mathrm{RT}}\right),
$$

is $6.91 \times 10^{-13} \mathrm{~m}^{2} / \mathrm{s}$. The diffusion distances $\mathrm{d}=$ $(\sqrt{\mathrm{Dt}})$ at this temperature for $100 \mathrm{~h}$ and $1000 \mathrm{~h}$ are $499 \mu \mathrm{m}$ and $1577 \mu \mathrm{m}$, respectively. In comparison with Fig. 6, it is evidenced that the depletion thicknesses of Zn-rich precipitates after aging at $150^{\circ} \mathrm{C}$ for durations of $100 \mathrm{~h}$ to $1000 \mathrm{~h}$ are about 15 -fold smaller than the diffusion distances of $\mathrm{Zn}$ atoms in the Sn matrix. The results indicate that the kineticscontrolled mechanism for the dissolution of Zn-rich precipitates in the $\mathrm{Au} / \mathrm{Ni}$ surface finished $\mathrm{Sn}-9 \mathrm{Zn}$ BGA packages is the interfacial reaction between $\mathrm{Sn}-9 \mathrm{Zn}$ solder and the $\mathrm{Ni}$ film on $\mathrm{Cu}$ pads, rather than the lattice diffusion of $\mathrm{Zn}$ atoms through the solder matrix.

The microstructure of the as-reflowed Sn-9Zn solder ball in a BGA package with $\mathrm{Ag} / \mathrm{Cu}$ pads, as shown in Fig. 6, also consists of many needlelike Zn-rich precipitates embedded in the Sn-rich ma- trix. However, in addition to those fine precipitates, a small number of coarsened Zn-rich plates also appear in the immersion Ag surface finished Sn-9Zn solder BGA packages. Figure 7 shows that the coarsened Zn-rich plates display a much greater tendency to form near the as-reflowed solder/pad interface. Those fine precipitates are found to diminish around the coarsened $\mathrm{Zn}$-rich plates. The reflow process also leads to the formation of a thin layer of scallopshaped intermetallic compounds at the interface of the solder joints. The chemical composition (at.\%) of these interfacial intermetallics, as analyzed by EDX,
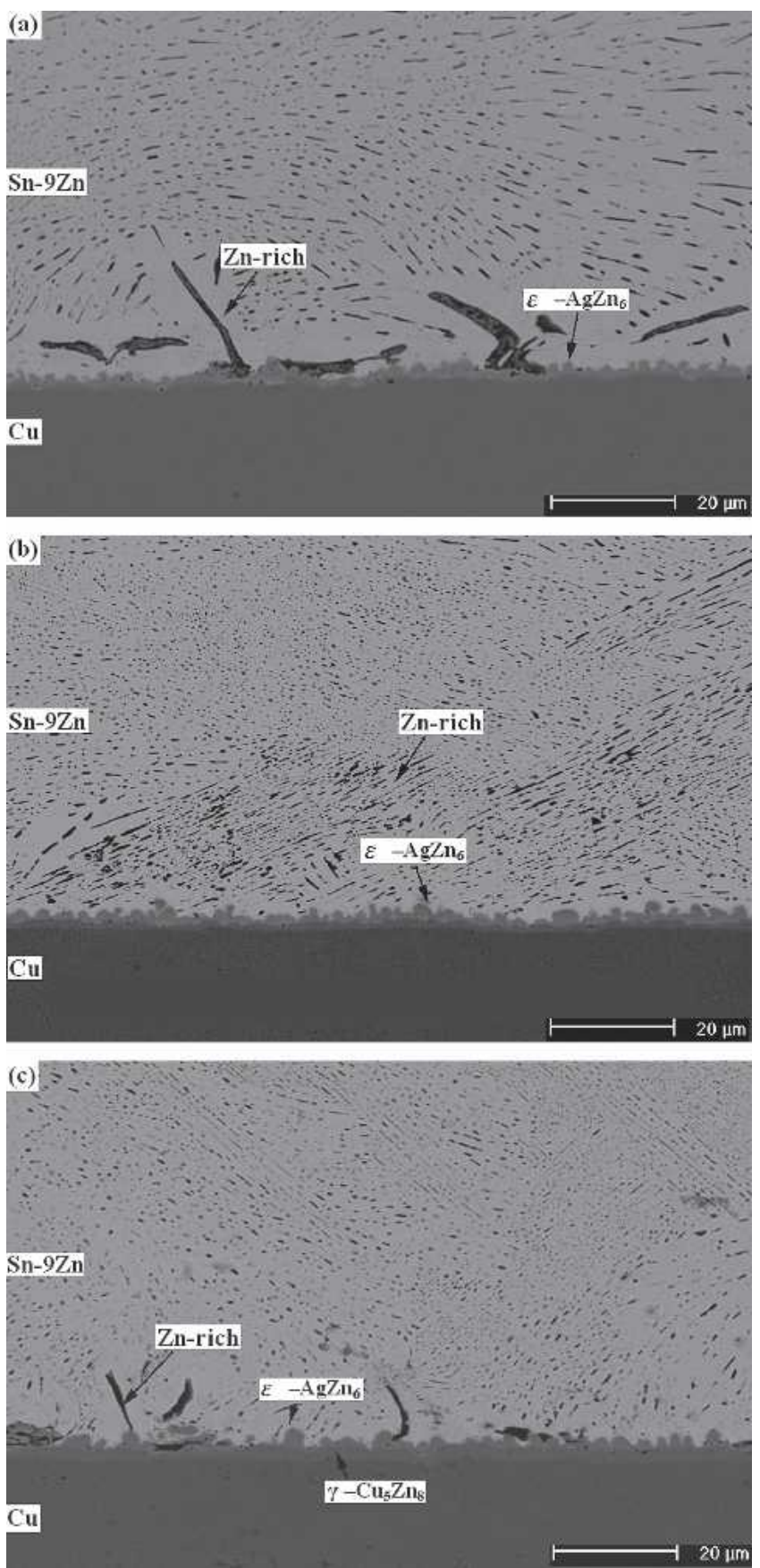

Fig. 7. Morphology of the intermetallic compounds formed at the interface of $\mathrm{Sn}-9 \mathrm{Zn}$ solder BGA packages with $\mathrm{Ag} / \mathrm{Cu}$ pads after multiple reflows: (a) one time, (b) two times, and (c) three times. 

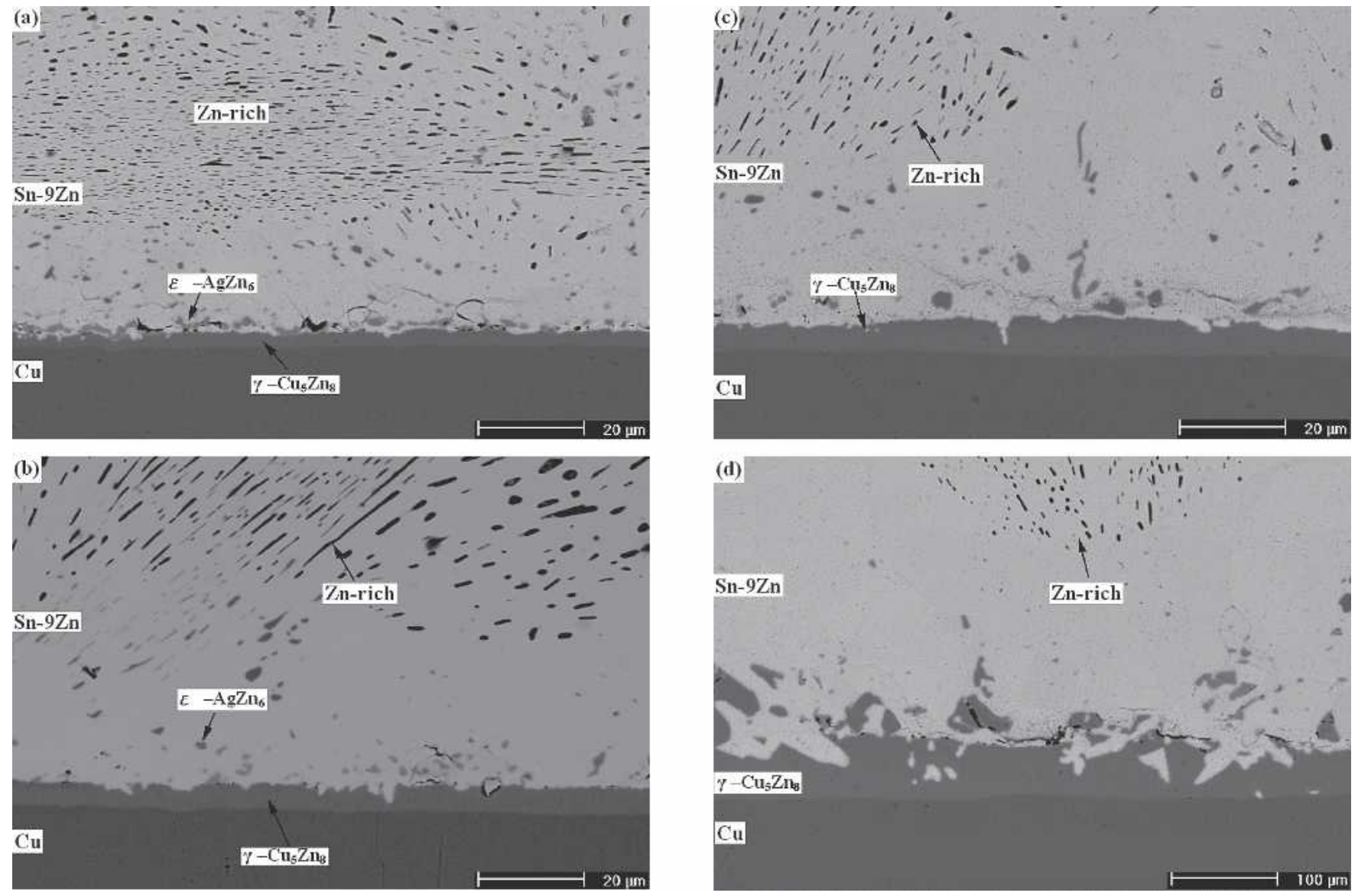

$\mathrm{Cu}$

Fig. 8. Microstructure of intermetallic compounds formed in the $\mathrm{Sn}-9 \mathrm{Zn}$ solder BGA packages with $\mathrm{Ag} / \mathrm{Cu}$ pads after aging at $100^{\circ} \mathrm{C}$ for various time periods: (a) $100 \mathrm{~h}$, (b) $300 \mathrm{~h},(\mathrm{c}) 700 \mathrm{~h}$, and (d) $1000 \mathrm{~h}$.
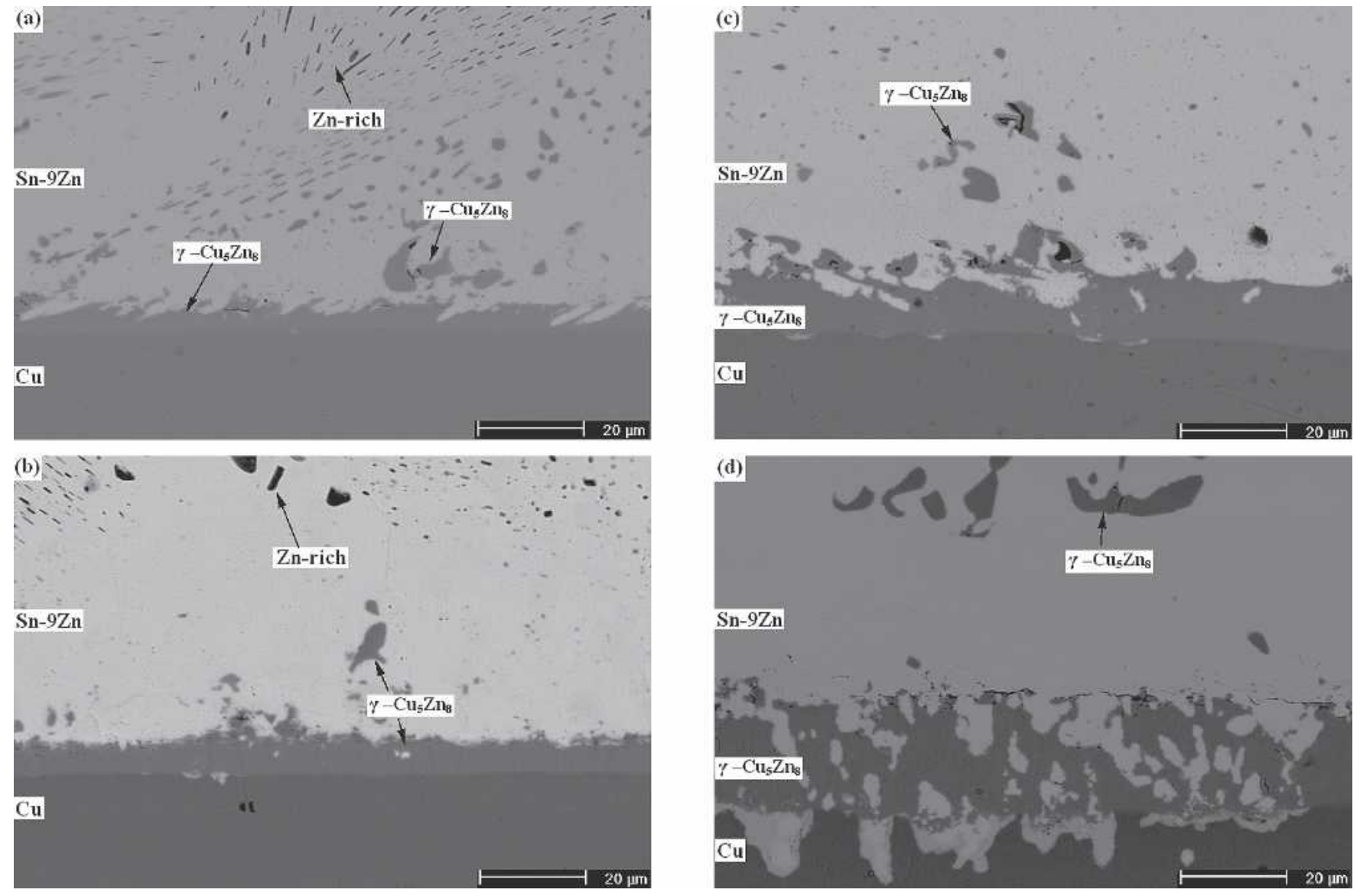

Fig. 9. Microstructure of intermetallic compounds formed in the $\mathrm{Sn}-9 \mathrm{Zn}$ solder BGA packages with $\mathrm{Ag} / \mathrm{Cu}$ pads after aging at $150^{\circ} \mathrm{C}$ for various time periods: (a) $100 \mathrm{~h}$, (b) $300 \mathrm{~h},(\mathrm{c}) 700 \mathrm{~h}$, and (d) $1000 \mathrm{~h}$. 

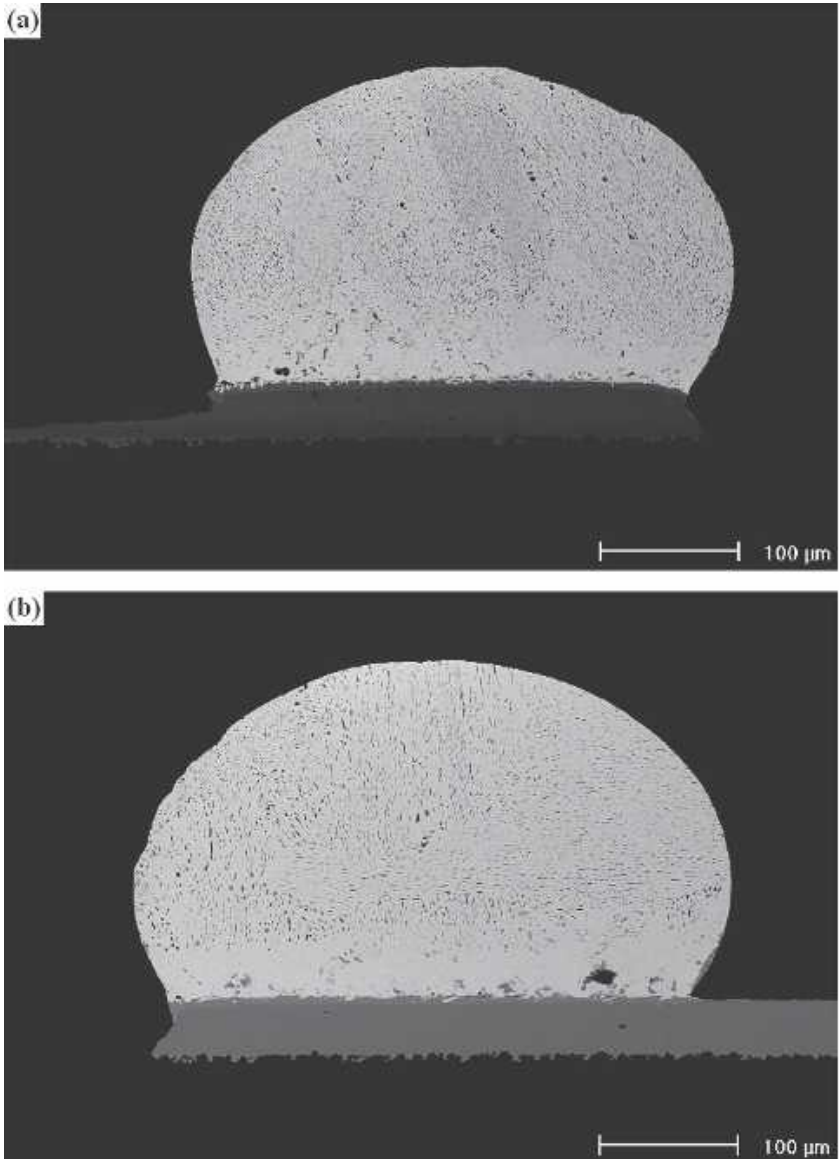
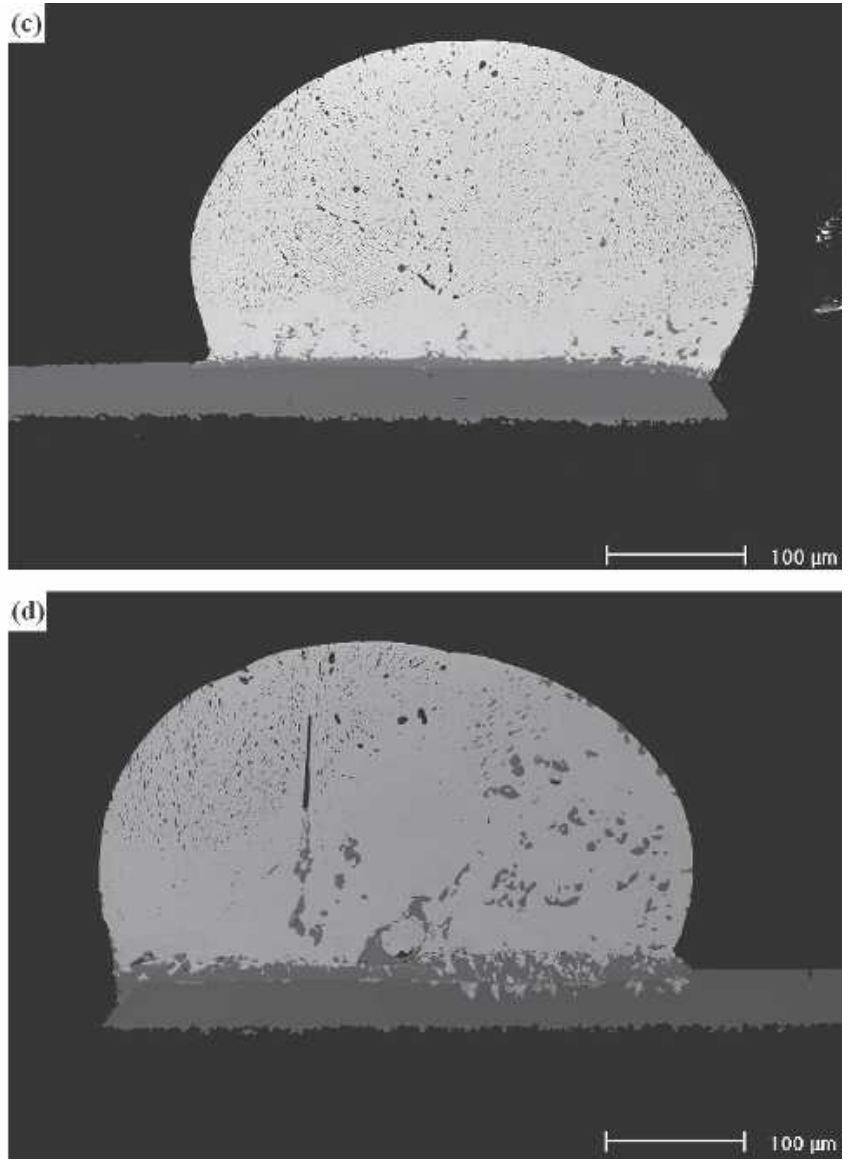

Fig. 10. Morphology of solder balls in Sn-9Zn BGA packages with $\mathrm{Ag} / \mathrm{Cu}$ pads after aging at various temperatures and time periods: (a) $100^{\circ} \mathrm{C}$ $300 \mathrm{~h}$; (b) $100^{\circ} \mathrm{C}, 1000 \mathrm{~h}$; (c) $150^{\circ} \mathrm{C}, 300 \mathrm{~h}$; and (d) $150^{\circ} \mathrm{C}, 1000 \mathrm{~h}$.

is $\mathrm{Ag}: \mathrm{Zn}=14.4: 85.6$, which corresponds to the $\varepsilon-\mathrm{AgZn}_{6}$ phase in the $\mathrm{Ag}-\mathrm{Zn}$ equilibria diagram. Figure 7 shows that the scallop-shaped $\varepsilon-\mathrm{AgZn}_{6}$ intermetallic has not altered much after multiple reflows. However, an additional intermetallic layer has formed between the $\varepsilon-\mathrm{AgZn}_{6}$ scallops and the $\mathrm{Cu}$ pad. The EDX analyses show that the composition (at.\%) of the new intermetallic layer is in the $\gamma-\mathrm{Cu}_{5} \mathrm{Zn}_{8}$ phase.

The $\gamma-\mathrm{Cu}_{5} \mathrm{Zn}_{8}$ intermetallic layer also appears at the interface (Fig. 8a) after aging of the singlereflowed specimen at $100^{\circ} \mathrm{C}$ for $100 \mathrm{~h}$. However, in Fig. $8 \mathrm{a}$, the $\varepsilon-\mathrm{AgZn}_{6}$ scallops are found to have detached from the $\gamma-\mathrm{Cu}_{5} \mathrm{Zn}_{8}$ intermetallic layer. Aged at $100^{\circ} \mathrm{C}$ for $300 \mathrm{~h}$, the $\varepsilon-\mathrm{AgZn}_{6}$ intermetallic scallops are observed (Fig. 8b) to have floated much farther away from the $\gamma-\mathrm{Cu}_{5} \mathrm{Zn}_{8}$ intermetallic layer. With further increases of the aging time, the $\varepsilon-\mathrm{AgZn}_{6}$ intermetallic compounds are dispersed in the solder matrix, and the $\gamma-\mathrm{Cu}_{5} \mathrm{Zn}_{8}$ layer has grown, as revealed in Fig. 8b-d. In Fig. 8, depletion of the Zn-rich precipitates can also be observed in the solder region near the interfacial $\gamma-\mathrm{Cu}_{5} \mathrm{Zn}_{8}$ intermetallic layers. The result indicates that the growth of $\gamma-\mathrm{Cu}_{5} \mathrm{Zn}_{8}$ intermetallics is caused by the reaction between the $\mathrm{Cu}$ pad and the $\mathrm{Zn}$ atoms from the solder matrix. The exhaust of the $\mathrm{Zn}$ content in Sn-9Zn solder appears to have caused the dissolu- tion of Zn-rich precipitates near the solder/pad interfaces.

After aging at $150^{\circ} \mathrm{C}$, many $\gamma-\mathrm{Cu}_{5} \mathrm{Zn}_{8}$ intermetallic compounds are observed to strip off and float into the solder matrix of the Ag-surface finished Sn-9Zn BGA packages, as shown in Fig. 9. After prolonged aging for $1000 \mathrm{~h}$, the thick $\gamma-\mathrm{Cu}_{5} \mathrm{Zn}_{8}$ intermetallic layer becomes porous, with the solder penetrated into the $\mathrm{Cu}$ pad in scallop form (Fig. 9d). The penetration of $\mathrm{Sn}-9 \mathrm{Zn}$ solder into the $\mathrm{Cu}$ pad can be easily observed in Fig. 10d, as compared to the morphology of the solder balls after aging under other conditions listed in Fig. 10.

The growth thickness of the $\gamma-\mathrm{Cu}_{5} \mathrm{Zn}_{8}$ intermetallic layer at the interfaces between the $\mathrm{Sn}-9 \mathrm{Zn}$ solder balls and the $\mathrm{Cu}$ pads after aging at $100^{\circ} \mathrm{C}$ and $150^{\circ} \mathrm{C}$ is plotted versus the square root of aging time. The linear relation in Fig. 11a implies that the growth kinetics of $\gamma-\mathrm{Cu}_{5} \mathrm{Zn}_{8}$ interfacial intermetallics is diffusion controlled. Since the source for $\mathrm{Zn}$ atoms in the growth of $\gamma-\mathrm{Cu}_{5} \mathrm{Zn}_{8}$ is the dissolution of Zn-rich precipitates in the solder matrix, the widths of the precipitate depletion regions at the aging temperatures of $100^{\circ} \mathrm{C}$ and $150^{\circ} \mathrm{C}$ are measured and plotted in Fig. 11b versus the square root of aging time. The linear relation of both curves indicates that the reaction is also diffusion controlled. The lattice diffusivities of $\mathrm{Zn}$ in $\mathrm{Sn}$ matrix at $100^{\circ} \mathrm{C}$ and 

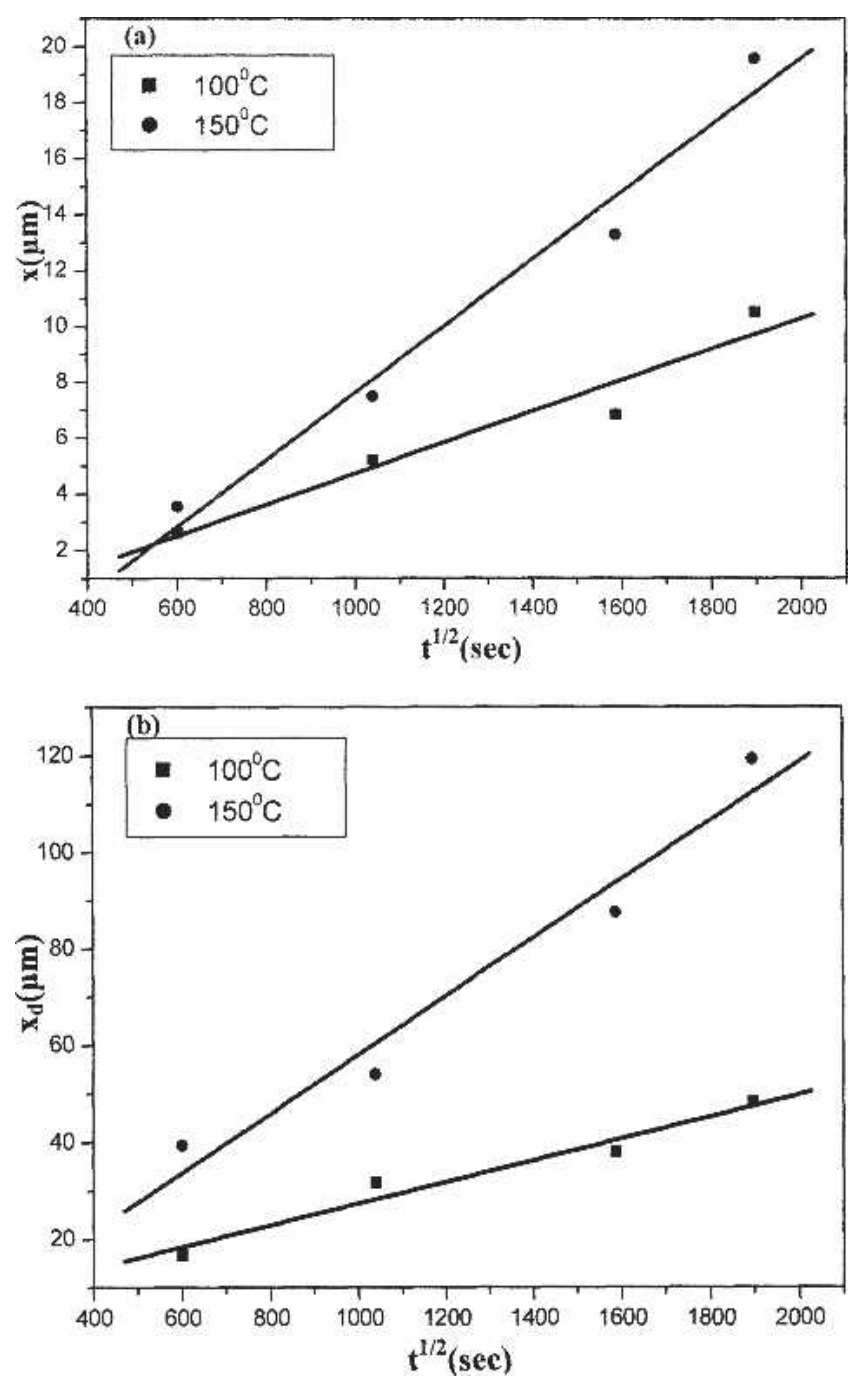

Fig. 11. Thickness $(x)$ of the $\gamma-\mathrm{Cu}_{5} \mathrm{Zn}_{8}$ interfacial intermetallic layer and precipitate-free zone $\left(x_{d}\right)$ in the solder matrix of immersion $\mathrm{Ag}$ surface finished $\mathrm{Sn}-9 \mathrm{Zn} \mathrm{BGA}$ packages after aging at $100^{\circ} \mathrm{C}$ and $150^{\circ} \mathrm{C}$ relative to the square root of time $\left(t^{1 / 2}\right)$.

$150^{\circ} \mathrm{C}$, as calculated from the equation of Huang and Huntington, ${ }^{17}$

$$
\mathrm{D}\left(\mathrm{m}^{2} / \mathrm{s}\right)=1.1 \times 10^{-6} \exp \left(-\frac{50.2 \mathrm{~kJ} / \mathrm{mol}}{\mathrm{RT}}\right),
$$

are $1.01 \times 10^{-13} \mathrm{~m}^{2} / \mathrm{s}$ and $6.91 \times 10^{-13} \mathrm{~m}^{2} / \mathrm{s}$. The diffusion distances $(\mathrm{d}=\sqrt{\mathrm{Dt}})$ at $100^{\circ} \mathrm{C}$ after aging times of $100 \mathrm{~h}$ and $1000 \mathrm{~h}$ are $191 \mu \mathrm{m}$ and $650 \mu \mathrm{m}$, respectively. For the aging temperature of $150^{\circ} \mathrm{C}$ for $100 \mathrm{~h}$ and $1000 \mathrm{~h}$, the diffusion distances of $\mathrm{Zn}$ atoms in Sn matrix are $499 \mu \mathrm{m}$ and $1577 \mu \mathrm{m}$, respectively. In comparison with Fig. 11a, it is evidenced that the depletion widths of Zn-rich precipitates during the aging treatments are about tenfold smaller than the diffusion distances of $\mathrm{Zn}$ atoms in $\mathrm{Sn}$ matrix. Similar to the former case, the $\mathrm{Au} / \mathrm{Ni}$ surface finished Sn-9Zn BGA packages, the results indicate that the controlled mechanism for the dissolution kinetics of $\mathrm{Zn}$-rich precipitates in the $\mathrm{Ag}$ surface finished solder joints is the interfacial reaction between the $\mathrm{Sn}-9 \mathrm{Zn}$ solder and the $\mathrm{Cu}$ pad, rather than the lattice diffusion of $\mathrm{Zn}$ atoms through the solder matrix.

The ball shear strengths of solder joints in Sn-9Zn BGA packages with $\mathrm{Au} / \mathrm{Ni} / \mathrm{Cu}$ and $\mathrm{Ag} / \mathrm{Cu}$ pads after various reflow and aging treatments are summarized in Table I. A single reflow cycle for $\mathrm{Au} / \mathrm{Ni}$ surface finished packages results in a bonding strength of $8.6 \mathrm{~N}$, which remains almost unchanged after multiple reflows, as shown in Fig. 12. For the Sn$9 \mathrm{Zn}$ solder joints with $\mathrm{Ag} / \mathrm{Cu}$ pads, the bonding strength decreased slightly from the single reflowed condition $(4.8 \mathrm{~N})$ to the three times reflowed condition $(4.3 \mathrm{~N})$. The results also indicated that the reflowed $\mathrm{Sn}-9 \mathrm{Zn}$ solder BGA packages with $\mathrm{Au} / \mathrm{Ni} / \mathrm{Cu}$ pads possessed ball shear strengths twofold higher than those with $\mathrm{Ag} / \mathrm{Cu}$ pads. Figure 13 compares the fractography of as-reflowed $\mathrm{Au} / \mathrm{Ni}$ and $\mathrm{Ag}$ surface finished solder joints after the ball shear test. It is evidenced that the Sn-9Zn BGA packages with Au/ $\mathrm{Ni} / \mathrm{Cu}$ pads fractured along the solder matrix with a fully ductile characteristic (Fig. 13a). However, Fig. $13 \mathrm{~b}$ and $13 \mathrm{c}$ demonstrate that the as-reflowed $\mathrm{Ag}$ surface finished Sn-9Zn packages after the ball shear test fractured along the solder/pad interface, with the exposure of the interfacial $\varepsilon-\mathrm{AgZn}_{6}$ intermetallic layer (referring to Fig. 7a). It has been shown in Fig. 2 that the interface between the Sn$9 \mathrm{Zn}$ solder and the $\mathrm{Ni} / \mathrm{Cu}$ pad after reflowing was free of intermetallic compounds. The much lower ball shear strength of the as-reflowed Ag surface finished Sn-9Zn packages, in comparison with those with the $\mathrm{Au} / \mathrm{Ni}$ surface finish, should be attributed to the existence of brittle $\varepsilon-\mathrm{AgZn}_{6}$ interfacial intermetallics in the former packages.

Aging at $100^{\circ} \mathrm{C}$ for $100 \mathrm{~h}$ causes the ball shear strengths of single reflowed Sn-9Zn packages with $\mathrm{Au} / \mathrm{Ni} / \mathrm{Cu}$ and $\mathrm{Ag} / \mathrm{Cu}$ pads to decrease drastically to $7.2 \mathrm{~N}$. With further increases of the aging time, the bonding strengths remain almost constant, as revealed in Fig. 13. The degradation of bonding strengths for both surface finished packages after aging at $150^{\circ} \mathrm{C}$ are similar to those of packages aged at $100^{\circ} \mathrm{C}$. Fractography of all aged Sn-9Zn packages with $\mathrm{Au} / \mathrm{Ni} / \mathrm{Cu}$ and $\mathrm{Ag} / \mathrm{Cu}$ pads after ball shear tests reveal a dimple characteristic (Fig. 15). The solder

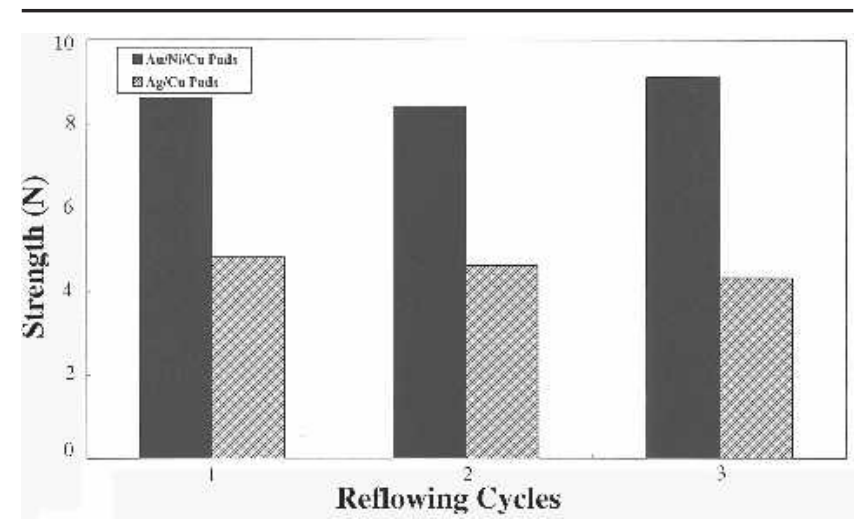

Fig. 12. Ball shear strengths of Sn-9Zn solder BGA packages with $\mathrm{Au} / \mathrm{Ni} / \mathrm{Cu}$ and $\mathrm{Ag} / \mathrm{Cu}$ pads after various reflow cycles. 
Table I. Ball Shear Strengths of the Sn-9Zn Solder BGA Packages with Au/Ni/Cu and Ag/Cu Pads after Various Reflow and Aging Treatments

\begin{tabular}{|c|c|c|c|c|c|c|c|c|}
\hline \multirow{3}{*}{$\begin{array}{l}\text { Surface } \\
\text { Finishing } \\
\text { Reflowing } \\
\text { Aging }\end{array}$} & \multicolumn{4}{|c|}{ Au/Ni/Cu Pads } & \multicolumn{4}{|c|}{ Ag/Cu Pads } \\
\hline & \multicolumn{2}{|c|}{$1 \times$ Reflowing } & \multirow[t]{2}{*}{$2 \times$ Reflowing } & \multirow[t]{2}{*}{$3 \times$ Reflowing } & \multicolumn{2}{|c|}{$1 \times$ Reflowing } & \multirow[t]{2}{*}{$2 \times$ Reflowing } & \multirow[t]{2}{*}{$3 \times$ Reflowing } \\
\hline & $100^{\circ} \mathrm{C}$ & $150^{\circ} \mathrm{C}$ & & & $100^{\circ} \mathrm{C}$ & $150^{\circ} \mathrm{C}$ & & \\
\hline 0 & $8.6 \mathrm{~N}$ & $8.6 \mathrm{~N}$ & $8.4 \mathrm{~N}$ & $9.1 \mathrm{~N}$ & $4.8 \mathrm{~N}$ & $4.8 \mathrm{~N}$ & $4.6 \mathrm{~N}$ & $4.3 \mathrm{~N}$ \\
\hline $100 \mathrm{~h}$ & $7.2 \mathrm{~N}$ & $7.2 \mathrm{~N}$ & - & - & $3.2 \mathrm{~N}$ & $2.9 \mathrm{~N}$ & - & - \\
\hline $300 \mathrm{~h}$ & $7.4 \mathrm{~N}$ & $7.5 \mathrm{~N}$ & - & - & $3.1 \mathrm{~N}$ & $2.7 \mathrm{~N}$ & - & - \\
\hline $500 \mathrm{~h}$ & $7.0 \mathrm{~N}$ & $7.3 \mathrm{~N}$ & - & - & $2.9 \mathrm{~N}$ & $2.5 \mathrm{~N}$ & - & - \\
\hline $700 \mathrm{~h}$ & $7.5 \mathrm{~N}$ & $7.4 \mathrm{~N}$ & - & - & $2.6 \mathrm{~N}$ & $2.5 \mathrm{~N}$ & - & - \\
\hline $1000 \mathrm{~h}$ & $7.0 \mathrm{~N}$ & $7.0 \mathrm{~N}$ & - & - & $2.7 \mathrm{~N}$ & $2.4 \mathrm{~N}$ & - & - \\
\hline
\end{tabular}
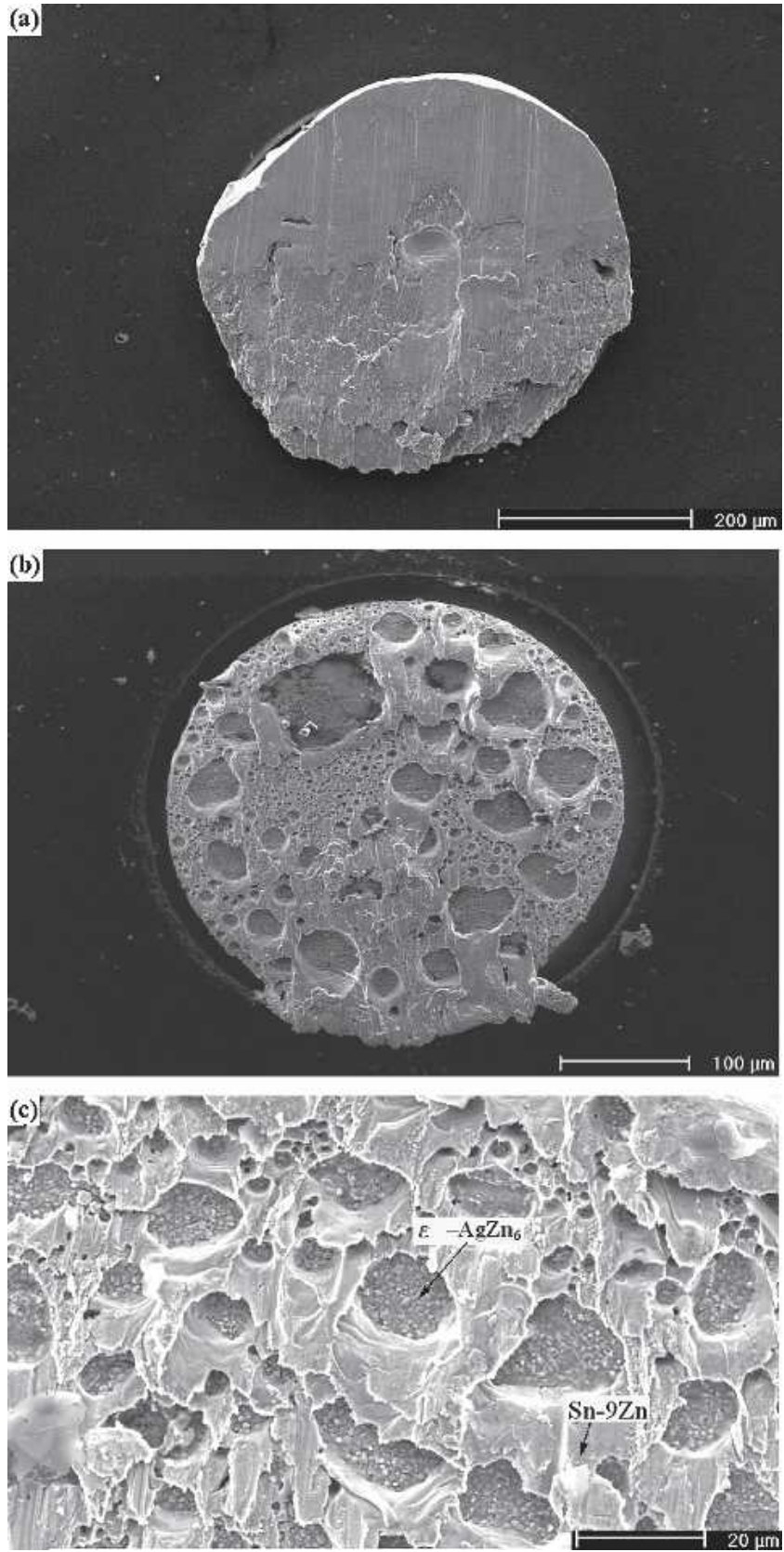

Fig. 13. Fractography of solder joints after ball shear tests in the as-reflowed Sn-9Zn BGA packages with various surface finishes: (a) $\mathrm{Au} / \mathrm{Ni} / \mathrm{Cu}$ pads and (b) and (c) Ag/Cu pads.

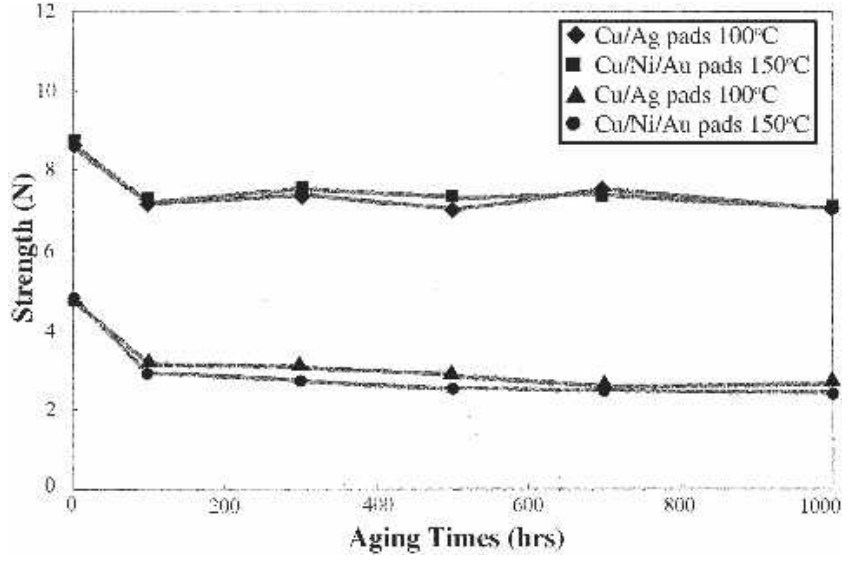

Fig. 14. Ball shear strengths of Sn-9Zn solder BGA packages with $\mathrm{Au} / \mathrm{Ni} / \mathrm{Cu}$ and $\mathrm{Ag} / \mathrm{Cu}$ pads after aging at $100^{\circ} \mathrm{C}$ and $150^{\circ} \mathrm{C}$ for various times.

joints have fractured along the solder matrix for those aged at either $100^{\circ} \mathrm{C}$ or $150^{\circ} \mathrm{C}$. The result implies that the appearance of the $\mathrm{Ni}_{4} \mathrm{Zn}_{21}$ and $\gamma-\mathrm{Cu}_{5} \mathrm{Zn}_{8}$ intermetallic layers at the solder/pad interface of $\mathrm{Au} / \mathrm{Ni}$ and $\mathrm{Ag}$ surface finished $\mathrm{Sn}-9 \mathrm{Zn}$ packages after aging at $150^{\circ} \mathrm{C}$ has not affected the bonding strength. To elucidate the degradation of bonding strengths in the aged solder joints, the hardness of the solder balls is measured and shown in Fig. 16. It is obvious that both tendencies of the ball strength (Fig. 14) and solder ball hardness (Fig. 16) are quite consistently related to the aging time. The results indicate that the strength degradation of solder joints in both surface finished packages after aging is caused by the softening of the solder matrix. The softening effect of Sn-9Zn solder balls with Au/ $\mathrm{Ni} / \mathrm{Cu}$ pads after aging is attributed to the depletion of $\mathrm{Zn}$-rich precipitates in both solder matrices due to the growth of the $\mathrm{Ni}_{4} \mathrm{Zn}_{21}$ and $\gamma-\mathrm{Cu}_{5} \mathrm{Zn}_{8}$ intermetallic layers, respectively. However, the depletion zones of $\mathrm{Zn}$-rich precipitates due to the formation and growth of the $\mathrm{Ni}_{4} \mathrm{Zn}_{21}$ intermetallic layer in the $\mathrm{Au} /$ $\mathrm{Ni}$ surface finished packages after aging are much narrower than those for Sn-9Zn solder joints with $\mathrm{Ag} / \mathrm{Cu}$ pads. From Fig. 14, the decrease in bonding strengths of $\mathrm{Au} / \mathrm{Ni}$ and $\mathrm{Ag}$ surface finished $\mathrm{Sn} 0-9 \mathrm{Zn}$ packages after aging processes are about $17 \%$ and $40 \%$, respectively. The much more severe degrada- 

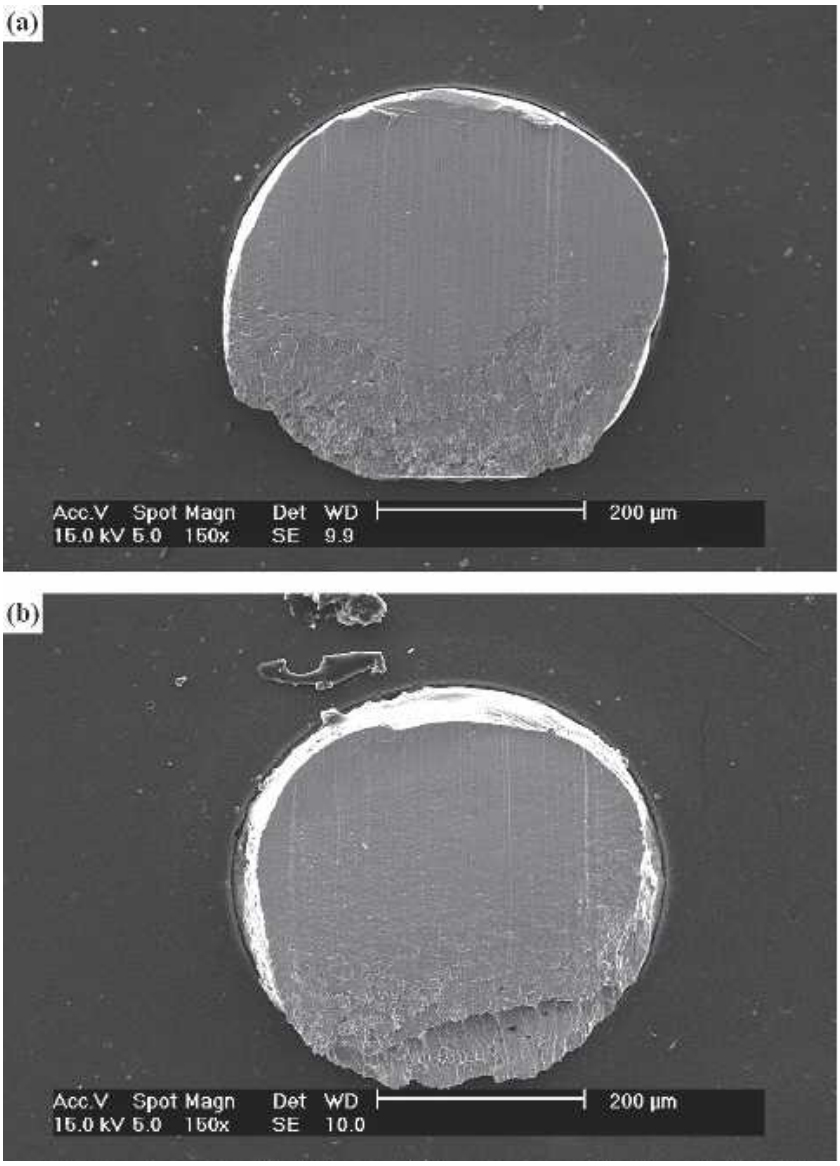
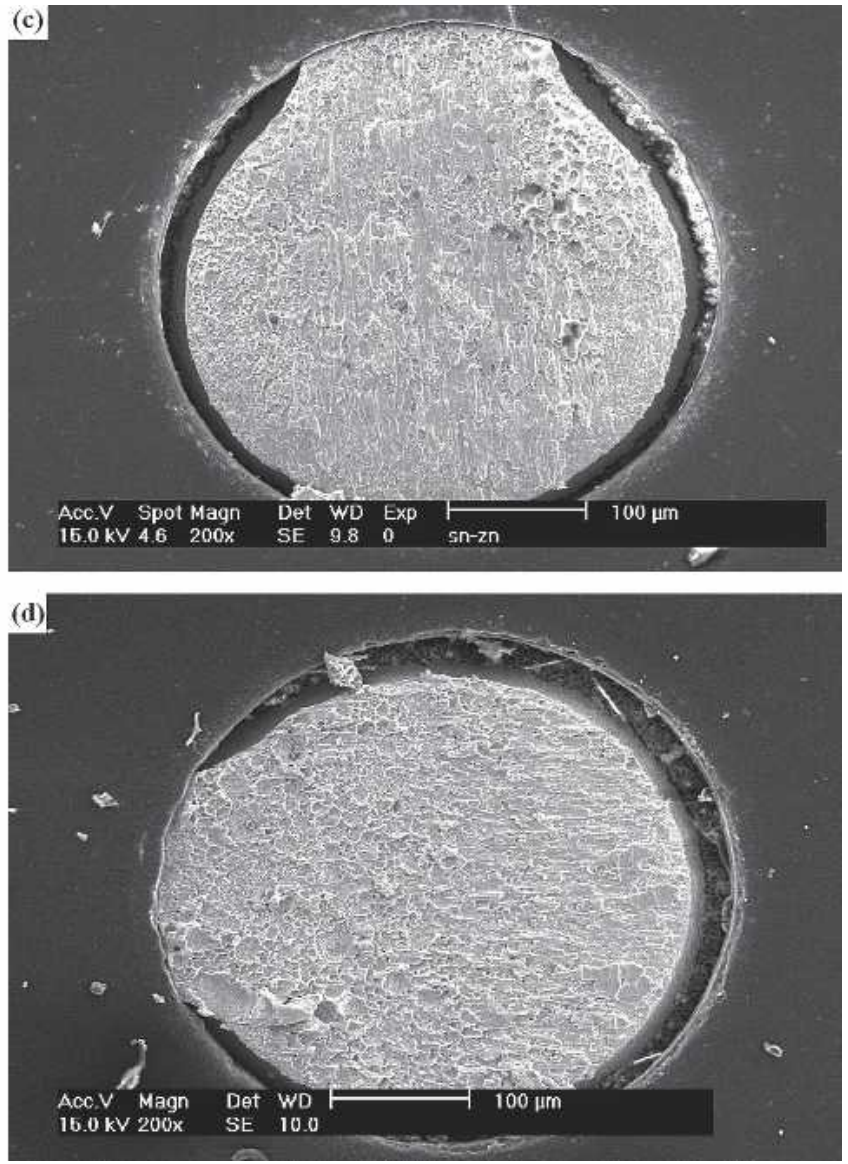

Fig. 15. Typical fractography of ball shear tested solder joints in $\mathrm{Sn}-9 \mathrm{Zn} \mathrm{BGA}$ packages with $\mathrm{Au} / \mathrm{Ni} / \mathrm{Cu}$ and $\mathrm{Ag} / \mathrm{Cu}$ pads after aging at various temperatures: (a) Au/Ni/Cu pads, $100^{\circ} \mathrm{C}$ aging; (b) Au/Ni/Cu pads, $150^{\circ} \mathrm{C}$ aging; (c) $\mathrm{Ag} / \mathrm{Cu}$ pads, $100^{\circ} \mathrm{C}$ aging; and (d) $\mathrm{Ag} / \mathrm{Cu}$ pads, $150^{\circ} \mathrm{C}$ aging.

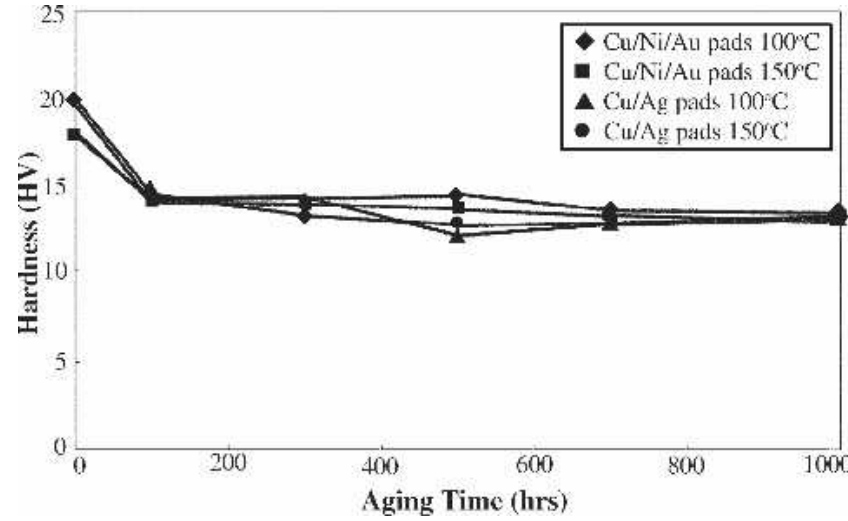

Fig. 16. Hardness of solder balls in Sn-9Zn BGA packages with $\mathrm{Au} / \mathrm{Ni} / \mathrm{Cu}$ and $\mathrm{Ag} / \mathrm{Cu}$ pads after aging at $100^{\circ} \mathrm{C}$ and $150^{\circ} \mathrm{C}$ for various times.

tion of aged solder joints in Sn-9Zn BGA packages with $\mathrm{Ag} / \mathrm{Cu}$ pads in comparison to those with $\mathrm{Au} / \mathrm{Ni} /$ $\mathrm{Cu}$ pads is consistent with the wider precipitate-free zones in the former case, which can be attributed to the higher growth rate of $\mathrm{Cu}-\mathrm{Zn}$ intermetallics than $\mathrm{Ni}-\mathrm{Zn}$ intermetallics at the solder/pad interfaces. ${ }^{11}$

\section{CONCLUSIONS}

The intermetallic compounds formed in $\mathrm{Sn}-9 \mathrm{Zn}$ solder joints of BGA packages with $\mathrm{Au} / \mathrm{Ni} / \mathrm{Cu}$ and $\mathrm{Ag} / \mathrm{Cu}$ pads after the reflow and aging processes are investigated. Experimental results show that the $\mathrm{Au}$ and $\mathrm{Ag}$ thin film dissolves rapidly during reflow and reacts with the $\mathrm{Zn}$ atoms of $\mathrm{Zn}$-rich precipitates embedded in the Sn-9Zn solder matrix to form a $\gamma_{3^{-}}$ $\mathrm{AuZn}_{4} / \gamma-\mathrm{Au}_{7} \mathrm{Zn}_{18}$ intermetallic double layer and $\varepsilon-\mathrm{AgZn}_{6}$ intermetallic scallops, respectively. Multiple reflows cause the $\gamma_{3 /} \gamma$ intermetallics in the $\mathrm{Au} /$ Ni-surface finished Sn-9Zn packages to float away from the $\mathrm{Ni} / \mathrm{Cu}$ pads. After aging at $100^{\circ} \mathrm{C}$ and $150^{\circ} \mathrm{C}, \gamma_{3}-\mathrm{AuZn}_{4}$ grows as a result of the reaction between $\gamma-\mathrm{Au}_{7} \mathrm{Zn}_{18}$ and the $\mathrm{Zn}$ atoms dissolved from Zn-rich precipitates near the $\gamma_{3} \gamma$ layer. At the interface between the $\mathrm{Sn}-9 \mathrm{Zn}$ solder and the $\mathrm{Ni} / \mathrm{Cu}$ pad, an additional $\mathrm{Ni}_{4} \mathrm{Zn}_{21}$ intermetallic layer appears at the aging temperature of $150^{\circ} \mathrm{C}$. For the immersion Ag surface finished Sn-9Zn BGA packages, it was observed that multicycle reflows caused an additional $\gamma-\mathrm{Cu}_{5} \mathrm{Zn}_{8}$ intermetallic layer to form between $\varepsilon-\mathrm{AgZn}_{6}$ scallops and the $\mathrm{Cu}$ pad. $\gamma-\mathrm{Cu}_{5} \mathrm{Zn}_{8}$ intermetallics also appeared after the aging of the reflowed specimens at $100^{\circ} \mathrm{C}$ and $150^{\circ} \mathrm{C}$. However,

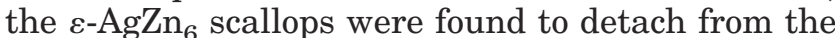
$\gamma-\mathrm{Cu}_{5} \mathrm{Zn}_{8}$ intermetallic layer and float into the solder matrix. The growth of $\mathrm{Ni}_{4} \mathrm{Zn}_{21}$ and $\gamma-\mathrm{Cu}_{5} \mathrm{Zn}_{8}$ interfacial intermetallics causes the depletion of $\mathrm{Zn}$ rich precipitates in the solder ball near the solder/ pad interfaces. Ball shear testing revealed that the as-reflowed $\mathrm{Sn}-9 \mathrm{Zn}$ BGA solder joints with $\mathrm{Au} / \mathrm{Ni} / \mathrm{Cu}$ 
and $\mathrm{Ag} / \mathrm{Cu}$ pads possessed bonding strengths of 8.6 $\mathrm{N}$ and $4.8 \mathrm{~N}$, respectively. The depletion of $\mathrm{Zn}$-rich precipitates near the solder/pad interfaces after the aging process accounts for the softening effect of the solder matrix. This resulted in degradation of the ball shear strength of $\mathrm{Au} / \mathrm{Ni}$ and $\mathrm{Ag}$ surface finished Sn-9Zn packages by about $17 \%$ and $40 \%$, respectively.

\section{ACKNOWLEDGEMENT}

The authors gratefully acknowledge the financial support from the National Science Council, Taiwan, for this study under Grant No. 93-2216-E002-024.

\section{REFERENCES}

1. N.C. Lee, Adv. Microelectron. 26, 29 (1999).

2. H.J. Lau, C.P. Wong, N.C. Lee, and S.W. Ricky Lee, Electronics Manufacturing with Lead-Free, Halogen-Free \& Conductive-Adhesive Materials (New York: McGraw-Hill Handbooks, 2003).

3. Z. Chen, M. He, and G. Qi, J. Electron. Mater. 33, 1465 (2004).

4. J.W. Yoon, S.W. Kim, and S.B. Jung, J. Alloys Compounds $391,82(2005)$.
5. M.Y. Chiu, S.Y. Chang, Y.H. Tseng, Y.C. Chan, and T.H. Chuang, Z. Metallkd. 93, 248 (2002).

6. Y.C. Chan, M.Y. Chiu, and T.H. Chuang, Z. Metallkd. 93, 95 (2002).

7. M.Y. Chiu, S.S. Wang, and T.H. Chuang, J. Electron. Mater. 31, 494 (2002).

8. P. Harris, Soldering Surf. Mount Technol. 11, 46 (1999).

9. R.K. Shiue, L.W. Tsay, C.L. Lin, and J.L. On, Microelectron. Reliab. 43, 453 (2003).

10. T.H. Chuang, H.M. Wu, M.D. Cheng, S.Y. Chang, and S.F. Yen, J. Electron. Mater. 33, 22 (2004).

11. Y.C. Chan, M.Y. Chiu, and T.H. Chuang, Z. Metallkd. 93, 95 (2002).

12. K. Suganuma and K. Niihara, J. Mater. Res. 13, 2859 (1998).

13. W.H. Lin and T.H. Chuang, Mater. Eng. Performance 12, 452 (2003).

14. H.M. Lee, S.W. Yoon, and B.J. Lee, J. Electron. Mater. 27, 1161 (1998).

15. S.W. Yoon, J.R. Soh, H.M. Lee, and B.J. Lee, Acta Mater. 45 , 951 (1997)

16. S.W. Yoon, W.K. Choi, and H.M. Lee, Scripta Mater. 40, 327 (1999).

17. F.H. Huang and H.B. Huntington, Phys. Rev. B9 1479 (1974). 